(C) 2016 by the Arizona Board of Regents on behalf of the University of Arizona. This is an Open Access article, distributed under the terms of the Creative Commons Attribution licence (http://creativecommons. org/licenses/by/4.0/), which permits unrestricted re-use, distribution, and reproduction in any medium, provided the original work is properly cited.

\title{
A MARINE RESERVOIR EFFECT $\triangle R$ VALUE FOR KITANDACH, IN PRINCE RUPERT HARBOUR, BRITISH COLUMBIA, CANADA
}

\author{
Kevan Edinborough $^{1 *} \cdot$ Andrew Martindale $^{2} \cdot$ Gordon T Cook $^{3} \cdot$ Kisha Supernant $^{4} \cdot$ \\ Kenneth M Ames ${ }^{5}$ \\ ${ }^{1}$ Institute of Archaeology, University College London, 31-34 Gordon Square, London, WC1H 0PY, United \\ Kingdom. \\ ${ }^{2}$ Department of Anthropology, University of British Columbia, Vancouver Campus, 6303 NW Marine Drive, \\ Vancouver, British Columbia, Canada, V6T 1Z1. \\ ${ }^{3}$ Scottish Universities Environmental Research Centre, Scottish Enterprise Technology Park, East Kilbride, Glasgow \\ G750QF, Scotland, United Kingdom. \\ ${ }^{4}$ Department of Anthropology, 13-15 HM Tory Building, University of Alberta, Edmonton, Alberta, Canada, T6G 2H4. \\ ${ }^{5}$ Portland State University, ANTH, P.O. Box 751, Portland, OR 97207.
}

\begin{abstract}
Prince Rupert Harbour (PRH), on the north Pacific Coast of British Columbia, contains at least 157 shell middens, of which 66 are known villages, in an area of approximately $180 \mathrm{~km}^{2}$. These sites span the last $9500 \mathrm{yr}$ and in some cases are immense, exceeding $20,000 \mathrm{~m}^{2}$ surface area and several meters in depth. Recent archaeological research in PRH has become increasingly reliant on radiocarbon dates from marine shell for developing chronologies. However, this is problematic as the local marine reservoir effect (MRE) remains poorly understood in the region. To account for the MRE and to better date the Harbour's sites, we propose a $\Delta \mathrm{R}$ of $273 \pm 38$ for the PRH area, based on our work at the site of Kitandach (GbTo-34), a massive shell midden-village centrally located within the Harbour. We followed the multiple paired sample approach for samples from specific contexts and ensured contemporaneity within the groups of marine and terrestrial materials by statistically assessing for outliers using the $\chi^{2}$ test. Taking together, the results for this and previous studies, it appears the MRE was fairly constant over the past $5000 \mathrm{yr}$.
\end{abstract}

KEYWORDS: Pacific Northwest, shell midden, archaeology.

\section{INTRODUCTION}

In 2011, A Martindale, K Ames, K Supernant, and K Edinborough initiated an archaeological project in Prince Rupert Harbour (PRH) (Figure 1) on the northern British Columbia coast. PRH has an extraordinarily rich archaeological record relevant to Northern Tsimshian history and to a range of questions about Northwest Coast and hunter-gatherer-fisher social and economic evolution. In an area of approximately $180 \mathrm{~km}^{2}$, the Harbour contains 157 currently recorded shell middens, of which 66 are classified as villages (Ames and Martindale 2014) (Figure 1). Consequently, the Harbour has seen archaeological research spanning the last century. The various goals of the current project, jointly funded by the Social Science and Humanities Research Council of Canada (SSHRC) and the National Science Foundation (NSF) of the United States, required refining the Harbour's settlement pattern history for the last $6000 \mathrm{yr}$. Achieving this goal necessitated establishing initial and terminal dates for a representative sample of the Harbour's village sites, and midden formation chronologies for a subset of middens. Accomplishing this demanded a large number of radiocarbon dates. We currently have 262 new dates from a range of contexts, including 38 village sites, 205 of which are from marine shell.

Despite its problems, using shell for building chronologies has advantages. In the coastal areas of British Columbia, Canada, and Alaska, USA, shell-bearing sites are ubiquitous and reflect both the byproduct of food consumption and engineering efforts to construct level, well-drained habitation terraces in a highly crenulated coastal landscape dominated by bedrock outcrops and wetlands. While dedicated construction episodes are known in which massive anthropogenic landforms are

\footnotetext{
*Corresponding author. k.edinborough@ucl.ac.uk.
} 


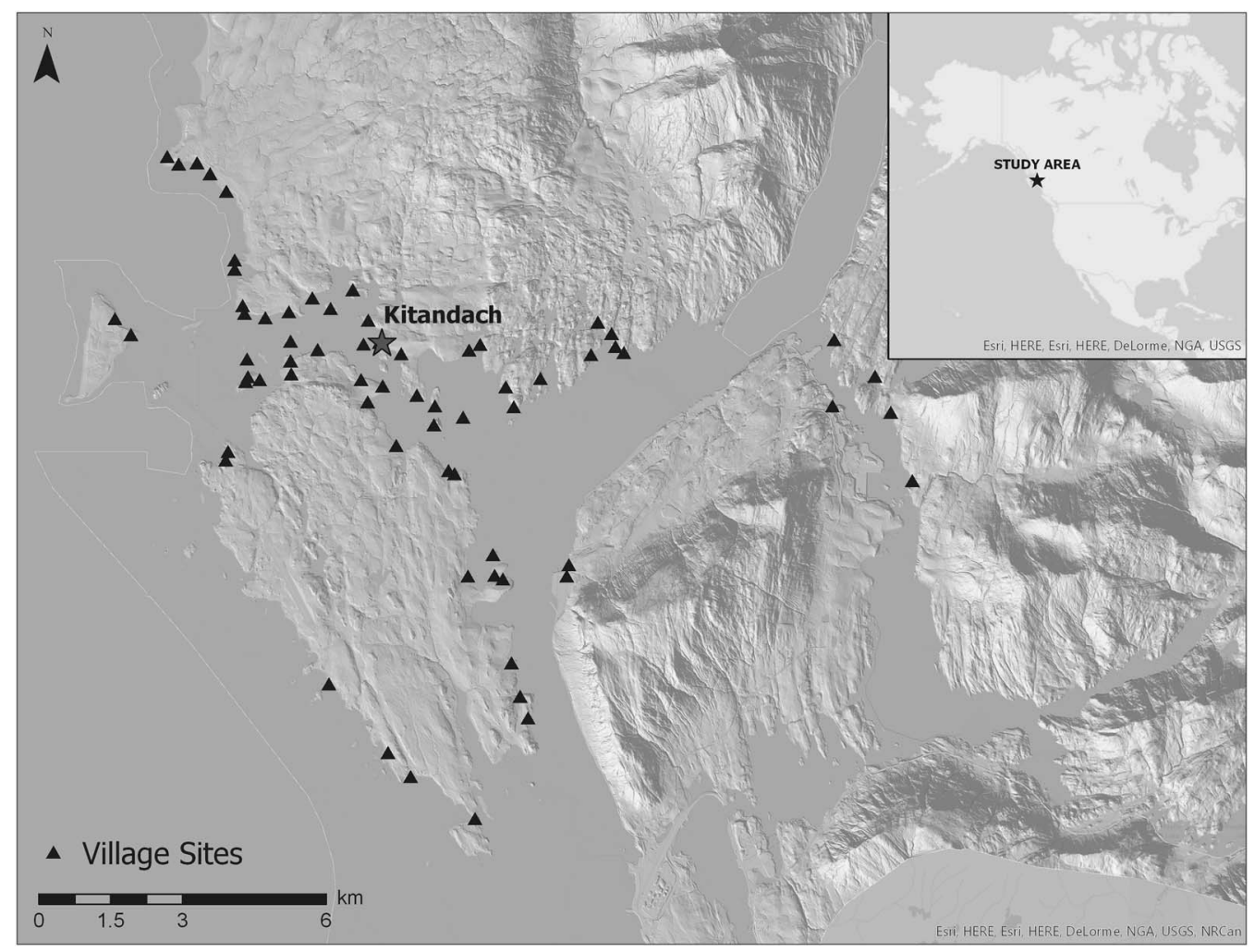

Figure 1 Map of Prince Rupert Harbour region

built in short periods of time (see Martindale et al. 2009), shell-bearing sites also capture recurring daily behaviors such that their lower and upper surfaces approximate the beginning and ending of occupation. Regional settlement patterns can be captured by large samples of dated basal and terminal components using ubiquitous marine shell, which is increasingly accessible via percussion coring (Cannon 2000; Martindale et al. 2009; Pluckhahn et al. 2015). Thus, a study of settlement patterns in this region and other coastal contexts is improved via the dating of marine shell. Our goal is to develop useful, accurate, and precise ages for marine-based archaeological samples, to be consistently calculated for a like-for-like comparison. Such a value is often perceived as less critical in some geological contexts, such as the construction of relative sea-level curves (Shugar et al. 2014), where chronological precision of fewer samples from longer time periods is valued over the accuracy of many samples from shorter intervals. Despite a history of ${ }^{14} \mathrm{C}$-based research, calculation of securely calibrated calendar ages from marine shell samples remains a large problem for archaeologists working in Prince Rupert Harbour and elsewhere on the Pacific Northwest coast, with variable effects from very deep water reservoirs, and other localized confounding geological processes, such as carbonate leaching (Hutchinson 2014; Reimer 2014). Although a global average surface water marine reservoir effect offset of approximately $400 \mathrm{yr}$ is well known, no consensus has been reached concerning the best way to approach this problem regionally or at the scale of the study area in Prince Rupert Harbour.

To highlight this issue and to suggest a way forward, we focus on one particularly important site in Prince Rupert Harbour (Figure 2), Kitandach (GbTo-34), using what we consider to be the 


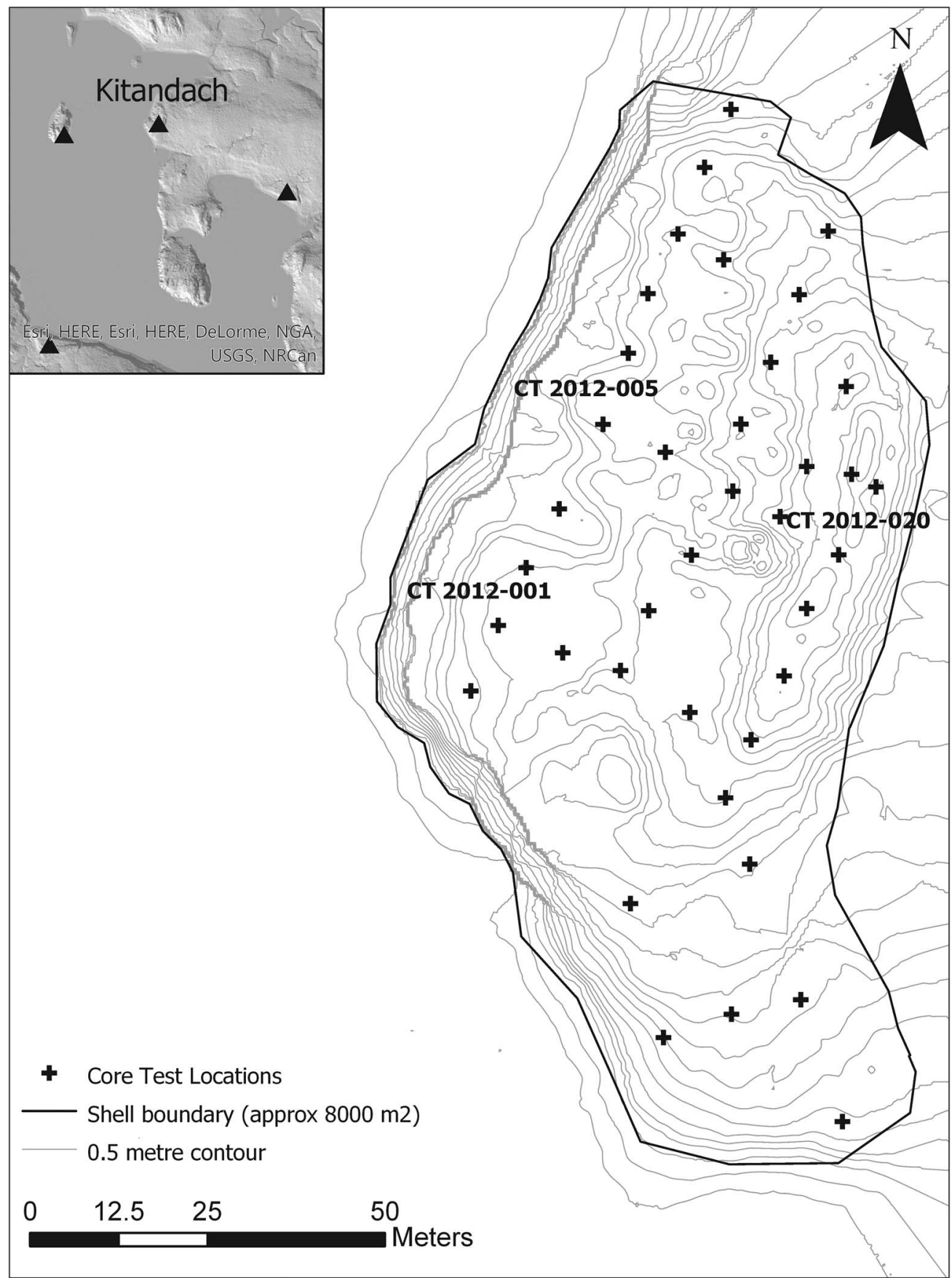

Figure 2 Map of the Kitandach (GbTo-34) site with the core test locations. Samples used in this study collected from labeled cores.

most robust methodology for $\Delta \mathrm{R}$ calculation, as developed by the Scottish Universities Environmental Research Centre (SUERC) in Russell et al. (2011) and Cook et al. (2015). In a seminal paper, Stuiver et al. (1986) defined the marine reservoir age as $\mathrm{R}(\mathrm{t})$, the difference in 
conventional (uncalibrated) ${ }^{14} \mathrm{C}$ age between synchronous samples from atmospheric and marine environments. They derived a marine calibration curve to model this offset, using the atmospheric $\Delta^{14} \mathrm{C}$ data and incorporating time-dependent variability in $\mathrm{R}(\mathrm{t})$ (Stuiver et al. 1986). This curve has been repeatedly updated and now accounts for the last 50,000 calibrated years BP (Marine13; Reimer et al. 2013). In addition to a temporally variable $\mathrm{R}(\mathrm{t})$, there are regional deviations from the contemporaneous global average $\mathrm{R}(\mathrm{t})$ value, which are a variable function of climate and oceanic circulation systems; these are expressed as $\Delta \mathrm{R}$ values to be used in conjunction with the Marine13 curve. Derivation of a $\Delta \mathrm{R}$ value for a specific region and time period can be calculated by a number of methods, but here we focus on one we consider to be particularly accurate. This method uses all statistical information contained within contemporaneous multiple paired marine and terrestrial samples obtained from discrete contexts formed over short time periods (Ascough et al. 2004, 2005). Following the latest SUERC research (Cook et al. 2015), the great advantage of taking multiple paired samples from a linked series of archaeological contexts is that the archaeological contexts and samples therein are not assumed to be coherent or correct, as outlying samples can be determined statistically using a simple chi-squared $\left(\chi^{2}\right)$ test of the marine and terrestrial data, before they are calibrated. The disadvantage of this approach is that even given ideal ${ }^{14} \mathrm{C}$ samples, the spatial-temporal range of suitable archaeological sites may be limited. We see this as an empirical problem as neighboring sites can be later compared. Perhaps more confounding are natural events such as tsunamis (McMillan and Hutchinson 2002), which may completely disturb the integrity of the deposits and yield nothing chronologically useful to measure. On the other hand, if deposits in a particularly coherent archaeological unit are disturbed, but there is no evidence of tsunami deposits, it is quite possible that interesting anthropogenic activity may be causal, so an imprecise set of results may be more useful than initially thought.

\section{SAMPLE EXTRACTION AND SELECTION}

Kitandach is a large shell-bearing site located in the Venn Pass/Metlakatla Pass area of PRH, spanning the period from about $5500 \mathrm{yr}$ ago to the 19th century (Figure 2). The upper component of the site is consistent with a major Tsimshian village with at least 17 visible structural depressions. It is unclear how deep the stratigraphy of the latest village form extends, but it is likely that the subsurface contains earlier villages, likely with different house and perhaps village forms, and possibly earlier non-village components such as shell terraces for camping and resource collection (see Martindale et al. 2009 for an example). Percussion coring was developed for the investigation of large shell-bearing sites (Cannon 2000; Martindale et al. 2009). The technique is simple in principle: a hollow $92.5-\mathrm{cm}(3-\mathrm{ft})$ long bit, $2.5 \mathrm{~cm}$ in diameter, containing a plastic liner, is hammered into the ground to retrieve samples of the subsurface. Extensions to the bit apparatus allow coring in $92.5-\mathrm{cm}$ increments to depths of over $10 \mathrm{~m}$. Each core is composed of a series of tubes representing the collection of subsurface material from the ground to below sterile geological parent material. Cultural components are highly visible (usually containing shell or charcoal), though compressed. Charcoal and shell can both present "old" problems that disassociate time of death from anthropogenic use. Unfortunately, the charcoal we could retrieve did not readily facilitate taxa identification. We mitigated this in Kitandach through sample selection of ubiquitous microscopic charcoal fragments and the selection of Mytilus sp. (likely Mytilus trossulus) for dating. Ubiquitous charcoal is more likely to derive from routine hearth use and thus is more likely to reflect regular harvesting of firewood. Mytilus sp. grows in rocky conditions and is harvested for consumption at maturity (4-5yr) and brought to residential sites. Finally, we identified and removed potential "old" samples using a $\chi^{2}$ test after ${ }^{14} \mathrm{C}$ analysis (cf. Burley et al. 2015). 
Within large village sites, multiple separate components are common, separated by potential paleosols of varying thicknesses, all of which are distinct from the basal geological parent material. At Kitandach (GbTo-34), we took 40 core tests at approximately $20-\mathrm{m}$ intervals across the site (Figure 2). We selected four samples each of charcoal and marine shell from three stratigraphic components (basal, terminal, and a mid-component transition) for MRE estimation.

\section{SAMPLE PRETREATMENT AND PROCESSING}

All methods including sample pretreatment, $\mathrm{CO}_{2}$ generation and purification, graphitization, and accelerator mass spectrometry (AMS) measurement were as described in Dunbar et al. (2016).

\section{$\Delta \mathbf{R}$ Calculation}

To calculate an accurate $\Delta \mathrm{R}$ value for Kitandach, we followed the SUERC methodology (Ascough et al. 2005; Russell et al. 2011; Cook et al. 2015), and employed a multiple paired sample approach to ensure contemporaneity between groups of marine and terrestrial materials by statistically assessing for outliers using the $\chi^{2}$ test. We sampled the shell midden extensively and obtained 24 shell/charcoal pairs, with four pairs of samples from each of three, separate, stratigraphic components within the shell midden (see Table 1).

Table 1 The samples, archaeological contexts, and ${ }^{14} \mathrm{C}$ data discussed in the text.

\begin{tabular}{|c|c|c|c|c|c|c|}
\hline Lab code & $\begin{array}{l}\text { Archaeological } \\
\text { context }\end{array}$ & $\begin{array}{l}\text { Sample } \\
\text { code }\end{array}$ & $\begin{array}{l}{ }^{14} \mathrm{C} \text { age } \\
\text { (yr BP) }\end{array}$ & $1 \sigma$ error & $\begin{array}{l}\delta^{13} \mathrm{C} \\
(\% 0)\end{array}$ & $\begin{array}{l}\text { Sample } \\
\text { type }\end{array}$ \\
\hline SUERC-44454 & CT 2012-001 & 70 & 3738 & 29 & -1.5 & Shell \\
\hline SUERC-44456 & CT 2012-001 & 71 & 4242 & 29 & -0.4 & Shell \\
\hline SUERC-44458 & CT 2012-001 & 72 & 4043 & 29 & 0.0 & Shell \\
\hline SUERC-44460 & CT 2012-001 & 73 & 3868 & 27 & -0.7 & Shell \\
\hline \multicolumn{7}{|c|}{$\chi^{2} T$ value $=172.57 ;$ Acceptance value $=7.81$} \\
\hline ŚUERC-44455 & CT 2012-001 & 82 & 3359 & 29 & -24.6 & Charcoal \\
\hline SUERC-44457 & CT 2012-001 & 83 & 3340 & 29 & -25.9 & Charcoal \\
\hline SUERC-44459 & CT 2012-001 & 84 & 3947 & 27 & -24.9 & Charcoal \\
\hline SUERC-44464 & CT 2012-001 & 85 & 3106 & 29 & -27.0 & Charcoal \\
\hline \multicolumn{7}{|c|}{$\chi^{2} T$ value $=503.55 ;$ Acceptance value $=7.81$} \\
\hline SUERC-44465 & CT 2012-005 & 74 & 4852 & 27 & -0.5 & Shell \\
\hline SUERC-44467 & СТ 2012-005 & 75 & 4898 & 29 & -0.3 & Shell \\
\hline SUERC-44469 & CT 2012-005 & 76 & 4886 & 27 & -0.4 & Shell \\
\hline SUERC-44474 & CT 2012-005 & 77 & 4854 & 29 & -0.1 & Shell \\
\hline \multicolumn{7}{|c|}{$\chi^{2} T$ value $=2.01 ;$ Acceptance value $=7.81$} \\
\hline SUERC-44466 & CT 2012-005 & 86 & 4218 & 29 & -24.6 & Charcoal \\
\hline SUERC-44468 & CT 2012-005 & 87 & 4182 & 27 & -26.0 & Charcoal \\
\hline SUERC-44470 & CT 2012-005 & 88 & 4176 & 27 & -27.9 & Charcoal \\
\hline SUERC-44475 & CT 2012-005 & 89 & 4216 & 27 & -26.0 & Charcoal \\
\hline \multicolumn{7}{|c|}{$\chi^{2} T$ value $=1.93 ;$ Acceptance value $=7.81$} \\
\hline SUERC-44476 & CT 2012-020 & 78 & 2239 & 29 & -0.6 & Shell \\
\hline SUERC-44478 & CT $2012-020$ & 79 & 2352 & 29 & -0.9 & Shell \\
\hline SUERC-44480 & CT 2012-020 & 80 & 2409 & 27 & -0.2 & Shell \\
\hline SUERC-44485 & CT 2012-020 & 81 & 2274 & 29 & -0.2 & Shell \\
\hline \multicolumn{7}{|c|}{$\chi^{2} T$ value $=3.93 ;$ Acceptance value $=5.99$} \\
\hline SUERC-44477 & CT 2012-020 & 90 & 1720 & 27 & -26.8 & Charcoal \\
\hline SUERC-44479 & CT 2012-020 & 91 & 1890 & 27 & -26.5 & Charcoal \\
\hline SUERC-44484 & CT 2012-020 & 92 & 1619 & 24 & -25.1 & Charcoal \\
\hline SUERC-44486 & CT 2012-020 & 93 & 1685 & 29 & -27.0 & Charcoal \\
\hline \multicolumn{7}{|c|}{$\chi^{2} T$ value $=7.21 ;$ Acceptance value $=5.99$} \\
\hline
\end{tabular}




\section{RESULTS}

Following the $\Delta \mathrm{R}$ calculation method of Cook et al. (2015), we performed $\chi^{2}$ tests on the samples to determine outliers and therefore potentially problematic contexts. Using samples that passed the test, we then calculated $\Delta \mathrm{R}$ and error values for every possible terrestrial/marine pair for each viable context. From this, a weighted mean $\Delta \mathrm{R}$ value was calculated for each context. The potential variability in the $\Delta \mathrm{R}$ value was calculated as the standard error for predicted values. This equates to the square root of the sum of the squares on the standard deviation of the weighted mean $\Delta \mathrm{R}$ value and the standard error. Only context 005 passed the $\chi^{2}$ test immediately (Table 1$)$. This provided a $\Delta \mathrm{R}$ value of $267 \pm 45$. The four charcoal age measurements were combined to provide a weighted mean ${ }^{14} \mathrm{C}$ age for this context of $4197 \pm 14{ }^{14} \mathrm{C}$ yr BP, which calibrates to 2885 to 2705 cal $\mathrm{BC}$ (95.4\% probability). Context 001 returned results that were too variable to be of use. When one outlier sample was removed from each of the marine and terrestrial groups from context 020 (SUERC-44479 and SUERC-44480) (Table 1), the remaining shell samples passed the outlier test while the charcoal samples only marginally failed the test. We performed the $\Delta \mathrm{R}$ calculations on the remaining samples. The $\Delta \mathrm{R}$ based on three remaining marine and terrestrial pairs was $288 \pm 69$. The weighted mean terrestrial age was $1675 \pm 30{ }^{14} \mathrm{C}$ yr BP, which calibrates to a calendar age range for this context of AD 265 to 425 (95.4\% probability).

\section{DISCUSSION AND CONCLUSIONS}

We have derived two useful $\Delta \mathrm{R}$ values for Kitandach, $267 \pm 45{ }^{14} \mathrm{C}$ yr for the period $2885-2705 \mathrm{BC}$ and $288 \pm 69$ for the period AD 265-425. In addition, using the 14CHRONO Marine Reservoir Database, held by Queen's University, Belfast, we derived a third, average value based on five values from the immediate area of Prince Rupert Harbour, derived by McNeely et al. (2006). These five values gave a weighted mean of $265 \pm 88$ for 19 th century data, where the error calculation is the standard error for predicted values, for consistency with our own data. Taken together, these data begin to suggest the possibility that the MRE for the Prince Rupert Harbour area has been relatively constant over approximately the past $5000 \mathrm{yr}$. This is entirely in line with the conclusions of Southon and Fedje (2003) for the wider British Columbia coast. They dated wood/shell pairs from natural beach deposits and archaeological midden sites and developed a record of reservoir ages extending back to $\sim 11,000 \mathrm{BC}$. Other regional studies have also yielded similar values (Hutchinson 2014), but have not taken the multiple paired sample approach developed by SUERC, which leaves them more prone to inadvertent statistical error. On the other hand, ideal multiple paired samples from clearly identifiable contexts can be very difficult to find in these crucial midden contexts without the appropriate methodologies, so researchers have understandably calculated a pragmatic $\Delta \mathrm{R}$ value whenever possible. $\Delta \mathrm{R}$ results from more pragmatic single-paired studies (e.g. Eldridge et al. 2014) may vary simply because their smaller samples sizes are measured over longer periods of time without a robust test for statistical outliers (see Cook et al. 2015).

We propose that more studies use the multiple paired sample approach as we quickly identified outliers and potentially problematic contexts. On the basis of our results, it would appear that a $\Delta \mathrm{R}$ value of $273 \pm 38$ (weighted mean of our two values) is a good estimate for this research area, a conclusion supported by the McNeely derived weighted mean value of $265 \pm 88$. The mixed context of 001 is suggestive of particularly intriguing anthropogenic activity that will be explored elsewhere.

\section{ACKNOWLEDGMENTS}

We wish to thank the following people and organizations: Lax Kw'alaams Indian Band, Metlakatla Indian Band, Susan Marsden, David Archer, Bryn Letham, Iain McKechnie, Ian 
Hutchinson, Eric Guiry, Steven Dennis, David Leask, and Phillipa Ascough. Also, SUERC staff are thanked for the ${ }^{14} \mathrm{C}$ sample preparations and measurements. ${ }^{14} \mathrm{C}$ dates were obtained through (US) National Science Foundation Grant Number 216847 awarded to Kenneth Ames as Principal Investigator. Samples for dating were collected through the Social Sciences and Humanities Research Council of Canada Grant Number 410-2011-0814 awarded to Andrew Martindale as Principal Investigator.

\section{REFERENCES}

Ames KM, Martindale A. 2014. Rope bridges and cables: a synthesis of Prince Rupert Harbour archaeology. Canadian Journal of Archaeology 38(1):140-78.

Ascough PL, Cook GT, Dugmore AJ, Barber J, Higney E, Scott EM. 2004. Holocene variations in the Scottish marine radiocarbon reservoir effect. Radiocarbon 46(2):611-20.

Ascough PL, Cook GT, Dugmore AJ. 2005. Methodological approaches to determining the marine radiocarbon reservoir effect. Progress in Physical Geography 29(4):532-47.

Burley D, Edinborough K, Weisler M, Zhao JX. 2015. Bayesian modeling and chronological precision for Polynesian settlement of Tonga. PLoS One 10(3):e0120795.

Cannon A. 2000. Settlement and sea-levels on the central coast of British Columbia: evidence from shell midden cores. American Antiquity 65(1):67-77.

Cook GT, Ascough PL, Bonsall C, Hamilton WD, Russell N, Sayle KL, Scott EM, Bownes JM. 2015. Best practice methodology for ${ }^{14} \mathrm{C}$ calibration of marine and mixed terrestrial/marine samples. Quaternary Geochronology 27:164-71.

Dunbar E, Cook GT, Naysmith P, Tripney BG, Xu S. 2016. AMS ${ }^{14} \mathrm{C}$ dating at the Scottish Universities Environmental Research Centre (SUERC) Radiocarbon Dating Laboratory. Radiocarbon 58(1):9-23.

Hutchinson I. 2014. The old shell game: Late Holocene variations in the marine reservoir effect in the Northeast Pacific. Paper presented at the 67th Northwest Anthropological Conference, Bellingham, WA.

Martindale A, Letham B, McLaren D, Archer D, Burchell M, Schöne BR. 2009. Mapping of subsurface shell midden components through percussion coring: examples from the Dundas Islands. Journal of Archaeological Science 36(7):1565-75.

McMillan AD, Hutchinson I. 2002. When the mountain dwarfs danced: aboriginal traditions of paleoseismic events along the Cascadia Subduction Zone of western North America. Ethnohistory 49(1):41-68.
McNeely R, Dyke AS, Southon JR. 2006. Canadian marine reservoir ages, preliminary data assessment, Open File 5049:3. Geological Survey Canada [WWW document]. URL http://geopub. nrcan.gc.ca, doi:10.4095/221564.

Pluckhahn TJ, Thompson VD, Cherkinsky A. 2015. The temporality of shell-bearing landscapes at Crystal River, Florida. Journal of Anthropological Archaeology 37:19-36.

Reimer PJ. 2014. Marine or estuarine radiocarbon reservoir corrections for mollusks? A case study from a medieval site in the south of England. Journal of Archaeological Science 49:142-6.

Reimer PJ, Bard E, Bayliss A, Beck JW, Blackwell PG, Bronk Ramsey C, Buck CE, Cheng H, Edwards RL, Friedrich M, Grootes PM, Guilderson TP, Haflidason H, Hajdas I, Hatté C, Heaton TJ, Hoffmann DL, Hogg AG, Hughen KA, Kaiser KF, Kromer B, Manning SW, Niu M, Reimer RW, Richards DA, Scott EM, Southon JR, Staff RA, Turney CSM, van der Plicht J. 2013. IntCal13 and Marine13 radiocarbon age calibration curves 0-50,000 years cal BP. Radiocarbon 55(4):1869-87.

Russell N, Cook GT, Ascough PL, Scott EM, Dugmore AJ. 2011. Examining the inherent variability in $\Delta \mathrm{R}$ : new methods of presenting $\Delta \mathrm{R}$ values and implications for MRE studies. Radiocarbon 53(2):277-88.

Shugar DH, Walker IJ, Lian OB, Eamer J, Neudorf C, McLaren D, Fedje D. 2014. Post-glacial sea-level change along the Pacific coast of North America. Quaternary Science Reviews 97:170-92.

Southon J, Fedje D. 2003. A post-glacial record of ${ }^{14} \mathrm{C}$ reservoir ages for the British Columbia Coast. Canadian Journal of Archaeology 27(1): 95-111.

Stuiver M, Pearson GW, Braziunas T. 1986. Radiocarbon age calibration of marine samples back to 9000 cal yr BP. Radiocarbon 28(2): 980-1021. 